УДК 811.161.1'1

DOI 10.52575/2712-7451-2021-40-2-234-245

\title{
Эвфемистическая репрезентация поступка «измена» в русской лингвокультуре
}

\author{
Бушуева Л.А. \\ Нижегородский государственный национальный исследовательский университет \\ им. Н.И. Лобачевского, \\ Россия, 603950, г. Нижний Новгород, пр. Гагарина, д. 23 \\ E-mail: sebeleva@yandex.ru
}

\begin{abstract}
Аннотация. Поступок представляет собой значимый элемент русской культуры, представление о нем рассматривается в данной работе как отражающее фрагмент языковой картины мира. Для анализа особенностей эвфемистической репрезентации типовой ситуации «измена» применяется несколько методов, в том числе методы направленного эксперимента и фреймового моделирования. В ходе исследования выявлены ключевые приемы, лежащие в основе эвфемизации измены: перенесение с вида на вид, мейозис, обобщение, замена прямой номинации иноязычной лексемой, метафора, прономинализация, использование диминутива. Контекстуальный анализ помогает определить границы поля эвфемизмов, обозначающих ситуацию измены, и отделить их от лексем, находящихся на стадии деэвфемизации. Совмещение методов лексикографического анализа, этимологического анализа, контекстуального анализа, фреймового моделирования, анализа приемов, лежащих в основе эвфемизации, способствует получению полной информации об изучаемом объекте, в частности о ситуации поступка «измена», и тем самым расширяет перспективы исследования в целом.
\end{abstract}

Ключевые слова: поступок, измена, фрейм, эвфемизм, стигма.

Для цитирования: Бушуева Л.А. 2021. Эвфемистическая репрезентация поступка «измена» в русской лингвокультуре. Вопросы журналистики, педагогики, языкознания, 40 (2): 234-245. DOI: $10.52575 / 2712-7451-2021-40-2-234-245$

\section{Euphemisms of Adultery in Russian Linguoculture}

\author{
Ludmila A. Bushuyeva \\ Lobachevsky State University of Nizhni Novgorod, \\ 23 Gagarina Av., Nizhni Novgorod, 603950, Russia \\ E-mail: sebeleva@yandex.ru
}

\begin{abstract}
A human act is viewed in this work as a significant element of Russian culture, a concept, which reflects a fragment of the linguistic world-image. In the furtherance of the analysis of euphemistic representation of the situation "adultery" the following methods are applied: the method of continuous sampling, which is aimed at figuring out the euphemistic words that are capable of naming the situation of adultery; the method of purposive sampling, which helps to find out the euphemisms that are used in modern speech and as nonce words; the etymological analysis, which contributes toward defining images that help to build the euphemistic meaning of the words and expressions that name the act of adultery. The attempt to build the frame model of the situation "adultery" is aimed at depicting the basic components of this model which emphasize different aspects of this situation, and at analyzing which components are represented by a larger or smaller number of euphemisms that helps to understand which elements of the situation arefocused more than others. One of the research objectives is to figure out the most popular devices that are used in the creation of euphemisms of adultery. The research shows that the most popular devices employed to disguise the act of adultery are generalization, the use of borrowed terms, diminutive words, meiosis, pronominalization, metaphor. The analysis of context meaning of the
\end{abstract}


euphemistic lexemeshelps to identify the words that are in the phase of losing euphemistic value. The combination of these methods contributes to deeper understanding of the semantic peculiarities of the lexemes under study and the situation they name.

Key words: act, adultery, frame, euphemism, stigma.

For citation: Bushuyeva L.A., 2021. Euphemisms of Adultery in Russian Linguoculture. Issues in Journalism, Education, Linguistics, 40 (2): 234-245. (in Russian). DOI: 10.52575/2712-7451-2021-40-2-234-245

\section{Введение}

Целью данного исследования является рассмотрение языковой репрезентации измены. Под изменой понимается 1) предательство, переход на сторону врага; 2) нарушение супружеской верности или верности в любви [Словарь русского..., 1981, с. 647]. В данной работе основное внимание уделяется измене в значении «нарушение супружеской верности или верности в любви». Не вызывает сомнений то, что измена является воплощением социально неприемлемого поведения и репрезентирует одну из неприглядных сторон жизни: «измена - коварное изменение чувств, мыслей и образа действий, противоположное верности и постоянству. Вызывает этическое и правовое осуждение» [Словарь русской..., 2014, с. 333]. Нечестное поведение, к которому относится измена, находит осуждение в кодексе ценностей на протяжении долгого времени и входит в систему стигм.

Будучи маркером испорченной идентичности, стигма меняет характер коммуникации: стремление избежать коммуникативного дискомфорта приводит к тому, что некоторые предметы и общественные явления по молчаливому согласию не называются прямо [Балли, 1961, с. 340]. Это обусловливает существование и функционирование в языке эвфемистических единиц. Эвфемизм, по определению исследователей, служит средством смягчения неприглядной действительности [Москвин, 2001, с. 61]; позволяет избежать коммуникативных неудач и конфликтов, оградить собеседника от коммуникативного дискомфорта [Крысин, 2000]. «Эвфемизмы в более вежливой форме - по сравнению с иными способами номинации - называют объект, действие, свойство» [Крысин, 2000, с. 391].

Поскольку доминирующей функцией эвфемизмов является функция вуалирования социально неприемлемого, большинство лингвистов рассматривают эвфемизмы как субституты неприличных, резких высказываний, которые могут обидеть собеседника [Neaman, Silver, 1995; Matthews, 1997; Гируцкий, 2005].

Значимым признаком эвфемизма является стигматичность денотата. Под стигмой мы, вслед за исследователями в области социологии и лингвистики [Афанасьев, Гилинский, 1993; Link, Phlean, 2001, p. 364; Торопцева, 2003, с. 17], понимаем дискредитирующую черту или качество, которая является неуместной у того или иного представителя группы с точки зрения обобщенных ожиданий. Качества, которые считаются нормальными и естественными для той или иной группы людей, определяются обществом. Принятая в обществе система моральных и этических норм выступает в роли регулятора поведения людей и определяет систему стигм - социально неприемлемых понятий или явлений. Таким образом, эвфемизм употребляется как способ вуалирования денотата, сокрытия за непрямой номинацией обличительного контекста.

Выбор слов напрямую зависит от нашего отношения к тому, о чем мы говорим. Следовательно, номинация неразрывно связана с оценкой. Вслед за А.М. Кацевым, полагаем, что важным признаком эвфемизмов является их негативная реакция на обозначаемое [Кацев, 1988, с. 54]. Характерная для эвфемизма стигматичность денотата, выбор эвфемизма вместо прямого наименования предмета или явления свидетельствуют о негативном отношении адресанта к данному предмету или явлению, или об осознании говорящим 
негативной социальной оценки обозначаемого явления. При этом стигматичность самого денотата не меняется.

\section{Объекты и методы исследования}

К денотатам, прямолинейное описание которых может вызвать негативное впечатление со стороны собеседника, относится ситуация измены. Для исследования особенностей языковой и речевой репрезентации данной ситуации были использованы дефиниционный анализ, метод сплошной выборки, контекстуальный анализ, метод направленного эксперимента, метод фреймового моделирования.

Дефиниционный анализ позволил выявить лексемы, которые являются прямыми номинациями различных элементов ситуации измены в лексической системе русского языка: измена, изменник, изменщик, изменница, изменщици. изменять, изменнический, изменнически, любовник, любовница. Отметим, что лексемы любовник и любовница использовались как эвфемизмы во второй половине XIX века в значении «влюбленный человек, возлюбленный», однако в настоящее время являются дисфемизмами [Сеничкина, 2008, с. 181].

С помощью метода сплошной выборки из «Словаря эвфемизмов русского языка» [Сеничкина, 2008], были отобраны общеязыковые эвфемизмы, обозначающие измену. Под общеязыковыми эвфемизмами мы, вслед за М.Л. Ковшовой, понимаем единицы языка, зафиксированные в словарях, устойчивые и легко воспроизводимые в речи большинством носителей языка [Ковшова, 2007, с. 53].

Анализ контекстов Национального корпуса русского языка (далее - НКРЯ), а также эксперимент со студентами и преподавателями ННГУ им. Лобачевского (общей численностью 80 человек), в рамках которого было предложено заменить слова измена, изменить, изменник, любовник, любовница на более мягкие, позволил очертить круг речевых эвфемизмов, способных репрезентировать ситуацию измены. Речевые эвфемизмы - это «такие индивидуально-контекстные замены, чья устойчивость и воспроизводимость ограничены узким кругом семейного или дружеского общения» [Ковшова 2007, с. 54]. С помощью данных, полученных в результате эксперимента, была также выделена группа окказиональных эвфемизмов, единиц, которые ограничены кругом общения, но в отличие от речевых эвфемизмов создаются на случай, иногда единственный, их употребления в речи.

\section{Результаты и их обсуждение}

К общеязыковым эвфемизмам, которые используются русскоязычными говорящими для эвфемистической (косвенной) объективации разных аспектов ситуации поступка «измена», относятся следующие эвфемизмы: адюльтер, неверность, интрижка на стороне, прелюбодеяние, ветреница, ветреничать, на стороне, на сторону ходить, налево ходить, наставить (приставить) рога, завести интрижку, близкий человек, возлюбленный, возлюбленная, друг, пассия, фаворит, фаворитка.

В качестве речевых эвфемизмов можно рассматривать следующие единицы: запретная любовь, обман, ложь, связь / роман / любовь / отношения / приключения / история на стороне, временное развлечение, обманщик, притворщик, перебежчик, любитель приударить, ветреник, ловелас, дамский угодник, ходок, гулена, иметь кого-то (у него / нее кто-то есть), быть с другим / другой, мотаться, гулять, гульнуть, дружить, погуливать, похаживать на сторону, мутить на стороне, что-то скрывать, хльстать по бабам, приударить за другими девушками, нарушить супружескую клятву, обманьвать, лгать, пуститься во все тяжкие, пойти в загул, волочиться за / не пропускать ни одной юбки, завести подружку, крутить шашни, непостоянный, любвеобильный, рыльце в пуш$\kappa y$, подруга (подружка). Данные выражения употребляются в НКРЯ для обозначения разных аспектов ситуации «измена».

Группа окказиональных эвфемизмов представлена единицами: физическая близость с другим человеком, уход налево, история на стороне, левачить, срывать розы в 
чужсм саду, молоть зерно в чужом сарае, человек с низкой системой ценностей, полиамор, любовное гнездышко.

Ситуацию поступка «измена» можно представить в виде фрейма. Фрейм - концептуальная структура, предназначенная для представления декларативных знаний о типизированной тематически единой ситуации [Баранов, 2003, с. 14].

Выделим типовые слоты в структуре фрейма «измена», которые получают эвфемистическую номинацию в русском языке.

Имя фрейма: прямая номинация - измена; эвфемистические номинации - адюльтер, неверность, прелюбодеяние, интрижка на стороне, запретная любовь, обман, ложь, связь / история / роман / любовь / отношения / приключения на стороне, временное развлечение, физическая близость с другим человеком, уход налево.

Слот «агент поступка и его свойства» актуализирует активного участника ситуации, целенаправленно совершающего поступок; свойства характера активного участника ситуации (в соответствии с классификацией семантических ролей Е.В. Кашкина и О.Н. Ляшевской [2013]). Прямые номинации: изменник, изменщик, изменница, изменщица; эвфемистические номинации: ветренища, ветреность, ветреник, ловелас, дамский угодник, ходок, гулена, человек с низкой системой ценностей, полиамор.

Слот «действие как проявление поступка». Любой поступок в своей основе имеет действие, реализованный акт воли человека. Прямая номинация: изменять; эвфемистические номинации: ветреничать, на сторону / налево ходить, похаживать на сторону, мутить на стороне, наставить (приставить) рога, завести / затеять интрижку, иметь кого-то (у него / нее кто-то есть),быть с другим / другой, мотаться, гулять, гульнуть, дружить, погуливать, что-то скрывать, хльстать по бабам, приударить за другими девушками, нарушить супружескую клятву, обманывать, лгать, пуститься во все тяжкие, пойти в загул, волочиться за / не пропускать ни одной юбки, завести подружку, крутить шашни, левачить, срывать розы в чужом саду, молоть зерно в чужом сарае.

Слот «контрагент поступка» подразумевает активного участника, задействованного в агентивной ситуации. Прямые номинации: любовник, любовница. Эвфемистические номинации: возлюбленный, возлюбленная, друг, пассия, подруга (подружка), фаворит, фаворитка.

Слот «пациенс поступка» - участник ситуации, претерпевающий самопроизвольно или под воздействием другого участника изменения. Эвфемистические номинации: рогоносеи, рогатый, рогатая.

Слот «оценка поступка, агента поступка» репрезентирует отношение к поступку, установление его соответствия нормам и принципам морали. Прямые номинации: изменнический, изменнически; эвфемистические номинации: ветреный, ветреная, непостоянный, любвеобильныий, рыльце в пушку.

Слот «место» подразумевает участок пространства, где локализуется ситуация поступка. Эвфемистическая номинация - на стороне, любовное гнездышко.

В фреймовой структуре ситуации поступка «измена» в наибольшей степени акутализирован слот «действие как проявление поступка», поскольку стигматично, главным образом, само действие. К ключевым элементам данного фрейма, судя по количеству выявленных эвфемистических единиц, являются также слоты «агент поступка, его свойства», «контрагент поступка» и «оценка поступка, агента поступка». Данные элементы ситуации в первую очередь подлежат «маскировке», что может быть мотивировано 1) желанием скрыть неприятную, возможно, пугающую сторону измены, 2) стремлением смягчить эффект высказывания, 3) представить себя или третьей стороны в более выгодном свете.

Выделяется достаточно обширная группа эвфемистических единиц, которые косвенно репрезентируют поступок «измена». В основе их образования лежат такие приемы, как мейозис - замена словом, выражающим «неполноту действия или слабую степень свойства» (Л.П. Крысин): неверность - эвфемизм образован посредством «от противно- 
го», с помощью префикса - не от соответствующего антонима. Эвфемизмы, основанные на отрицании противоположного, выражают «сдержанное порицание» для отрицательно оцениваемых свойств [Апресян, 1995, с. 312].

Лексема неверность позволяет говорящему смягчить эффект высказывания, частично снять ответственность за поступок: «Ты же, в принциипе, ему верна? Даже если ть ему изменяешь, то это вовсе не предательство или измена, а только неверность, шалость, момент, счастливая секунда. Почему нет?» [Гиголашвили, 2009]. Примечательно, что лексема шалость рассматривается в «Словаре эвфемизмов русского языка» как эвфемизм, обозначающий половые отношения: «о несерьезной, кратковременной любовной связи» [Сеничкина, 2008, с. 451].

Эвфемизмы адюльтер и прелюбодеяние - примеры использования иноязычных заимствований и слов из «более высоких» сфер языка в отношении к повседневному языку [Видлак, 1965, с. 275]. Вероятно, способность лексемы адюльтер выполнять эвфемистическую функцию объясняется особым очарованием этого слова, своеобразным французским шармом: «иноязычные слова меньше шокируют и кажутся более благородными» [Видлак, 1965, с. 278].

Прямая номинация может заменяться наименованием соответствующего родового понятия, как в случае с лексемами обман, ложь, которые относятся к лексике большого семантического потенциала и выражают поступок «измена» лишь в общих чертах.

Перенесение с вида на вид - прием, лежащий в основе образования эвфемизмов запретная любовь, временное развлечение.

Эвфемизмы, заполняющие слот «действие как проявление поступка», способствуют вытеснению нежелательных сем в импликационал и проникновению в интенсионал «случайных сем» [Шейгал, 2000, с. 207], т.е. вытесняются значения семы «нарушать верность» и выдвигаются в интенсионал семы «уходить», «временно отсутствовать» (на сторону / налево ходить, пойти в загул и др.), «наделять» (наставить / приставить рога), «приобретать» (завести интрижку, срывать розы в чужом саду).

К наиболее употребительным выражениям относятся ходить налево / на сторону и их вариации (сходить / поход / уход / гулять налево, левачить; у него есть история/ приключения / связь на стороне, похаживать на сторону, мутить на стороне), наставить рога, иметь кого-то (у него / нее кто-то есть).

Многие исследователи обращают внимание на то, что не всегда просто определить, действительно ли мы имеем дело с эвфемизмом или нет. Рассмотрим выражения ходить налево, ходить на сторону, наставить рога.

Этимология данных фразеологизмов достаточно глубоко исследована в лингвистике. В основе выражения ходить налево лежит представление о нарушении закона, о том, что противоположно добру, благу. «В мифологической модели мира противопоставление «правый - левый» отражает центральную нравственную антиномию «добро - зло». Так, слово правый используется в положительном значении, связанным с правдой, а левыц - в отрицательном значении, связанном с ложью» [Киселева, 2012, с. 11]. Ср.: «левый - активная сила, уводящая с прямого пути, в сторону от правды. Левое свидетельствует о приверженности скверне и пороку; склонно ко лжи и нарушению закона (ходить / глядеть налево, левачить, левый товар)» [Словарь русской..., 2014, с. 400]. Вспомним также, что для большинства мифологий характерно использование признака «левый» в значении отрицательного: многие славянские поверья, отраженные в русских приметах типа «плюнь через левое плечо», а также представление о том, что на правой руке собираются добрые поступки, а на левой - неблаговидные деяния. Вместе с тем в большинстве культурных традиций левая рука выступает в качестве женского символа [Токарев, 2008, с. 581]. Уже в самых ранних археологических памятниках прослеживаются следы выделения в жилище мужской и женской части. Левая сторона считается женской, а правая - мужской [Байбурин, 2005, с. 12]. Таким образом, в русском языковом сознании укоренилось противопо- 
ставление «правый - левый», которое соотносится с оппозициями «мужской - женский», «добро - зло».

Фразеологизм на стороне имеет значение «не там, где работает или живет» [Словарь русского ..., 1981], т.е. развлекаться, гулять вне семьи. Концепт сторона соотносится с духовным кодом культуры, т.е. с совокупностью нравственных ценностей и установок человека. В духовном коде культуры под влиянием христианства сформировалось представление о том, что развлечения, особенно сексуального характера, за пределами семьи, являются предосудительными [Красных, 2016, с. 394].

С одной стороны, в современной речи данные выражения могут выглядеть несколько резкими и скорее заострять внимание на деликатной теме, чем смягчать ее. С другой стороны, данные фразеологизмы объединяет их способность представлять ситуацию измены в юмористическом ключе, что, в определенной степени, способствует нейтрализации неприятных ассоциаций, связанных с изменой. Ср.: «У одной моей подруги есть супруг, очень обеспеченный человек, который каждый раз, сходив налево, приходит домой - и у него каждый раз висит шуба через плечо» [Джоваева, 2011]; «Хиллари не поддержали честные мужнины жены, не простившие супруге президента лояльного отношения $к$ Билловым походам налево от супружеской кровати» [Быков, Деркач, 2003].

Уместно привести здесь точку зрения Э. Партриджа, который отмечает, что «внешне грубой формой не нарушается основная функция эвфемизма - камуфлировать неприятное содержание» [цит. по: Кацев, 1988, с. 55]. Многие речевые и окказиональные эвфемизмы «замешаны» на иронии, с помощью которых говорящий дистанцируется от какого-либо события и ставит себя в сильную позицию «эксперта» [Ковшова, 2007, с. 55]. Возможно, это в определенной степени характерно и для рассматриваемых эвфемизмов.

Использование выражений ходить налево, ходить на сторону- это попытка высмеять явление, которое, во-первых, относится к сфере интимных отношений, обращение к которой всегда вызывает дискомфорт, во-вторых, является нежелательным и может иметь серьезные негативные последствия для участников ситуации: «Сходил было налево, а жена в профком жалобу» [Богомолов, 2001].

С помощью данных эвфемизмов измена представляется как нечто несерьезное и вполне обыденное. Такой эффект достигается благодаря ассоциациям с выражениями ходить на работу / в гости / в магазин / гулять, обозначающими рутинные действия, которые регулярно повторяются и находятся за рамками категории оценки. Измена как бы переносится из категории поступка в категорию действия, лишаясь, таким образом, значимости и оцениваемости.

С помощью выражений похаживать на сторону, погуливать не только преуменьшается отрицательная оценка поступка «измена», но и подчеркивается его нерегулярный характер: «похаживать - ходить, приходить куда-либо время от времени» [Словарь русского ..., 1981, с. 339], «погуливать - время от времени гулять, кутить, вести распутный образ жизни» [там же, с. 170]. Ср.: «Пил он как дьявол, столярное дело знал ангельски, любил поозорничать, посмеяться, посплетничать, а может, - кто его знает? - еще и вправду погуливал» [Домбровский, 1966].

Примечательно, что идея об однократности или кратковременности поступка подчеркивается во многих контекстах, включающих эвфемизмы, репрезентирующие измену таким образом преуменьшается разрушительная сила измены: «Жена просит считать свою измену временным помутнением» [Истории измен..., 2019-2021]; «Оказалось, что он недавно развелся с женой и находится в депрессии, поэтому нашел себе такое временное развлечение, как я. Мне стыдно об этом не только говорить, но и признаться самой себе» [Исповедь нашей..., 2020].

На то, что выражения ходить на сторону / налево по-прежнему можно считать эвфемизмами, указывают также: 
1) невербальные экспликаторы, к которым относятся, например, заключение эвфемизма в кавычки: «Если женщину бросил муж или стал похаживать "на сторону" $и$ проверка на порчу подтвердила ее наличие, следует поступать таким образом» [От порчи..., 2019]; «Надоели серые будни, захотелось ярких впечатлений, и вы надумали завести роман "на стороне"»? [Роман «на стороне» ..., 2019];

2) контекстуальное окружение эвфемизма: «- Bbl о любовнище? Возможно, Леня имел какие-то приключения на стороне, но я не в курсе этого» [Троицкий, 2000] - содержащееся в тексте прямолинейное любовница обнаруживает контраст с эвфемистическим обозначением измены; «У меня было много друзей в возрасте 35-40, почти все поголовно прошли через это. Большинство живут с женами, хотя кое-кто развелся, я, например. Часто и женщины пытаются что-то на стороне мутить, кстати» [Муж нашел..., 2013] - использование выражения мутить на стороне представлено наряду с единицей это (пройти через это), эвфемизмом, созданным с помощью приема прономинализации, что также говорит в пользу его эвфемистической функции.

Местоимения это, кто-то, что-то заменяют в речи лексемы измена, изменить, любовница, любовник, таким образом, благодаря прономинализации, происходит ослабление значения «измена» и актуализация отвлеченного значения: «- Мне кажется, у него кто-то есть, - вдруг призналась Таня и опять заплакала. Ей нужно было с кем-то поговорить» [Трауб, 2012]; «Оттого, что он, по ее словам, так демонстративно избегает с ней танцевать, люди могут подумать, что между ними что-то есть, тогда как между ними ничего нет» [Искандер, 1989].

Выражение завести интрижку, подобно выражениям ходить на сторону / налево/гульнуть, за счет диминутива интрижка также фокусирует внимание на незначительности измены. Несмотря на эмоцию пренебрежения, которую передает данная лексема, контексты с ней указывают в первую очередь на то, что отношения, называемые интриж$\kappa о и ̆,-$ не больше, чем кратковременная связь, не имеющая будущего, в то время как прямая номинация измена всегда акцентирует внимание на значительности поступка, его неизбежных разрушительных последствиях. Ср.: «Жизнь и так тоскливая, а небольшая интрижкка на стороне добавит тонуса браку» [Сухов, 2007]; «Ведь у них с Ваней, например, далеко не дачная интрижка - то есть нечто преходямее и незамысловатое» [Тронина, 2004]; «С другой стороны, если из-за легкой, ничего не значащей «интрижки» ставится под угрозу семейная жизнь и будущее детей, мы поможем незадачливому ловеласу» [Фрумкин, 2002].

Эвфемистичность лексемы интрижкатакже обеспечиваетсяконнотацией неопределенности, свойственной данной единице: интрижка - не всегда именно измена, это и простой флирт, безобидные отношения с намеком на роман: «Мало кто из дам доводит интрижку до измены в постели» [Шеховцова и др., 2001]; «С тревогой она писала брату поэта Н.И. Тютчеву в Вену: «Теодор легкомысленно позволяет себе маленькие светские интрижки, которые, как бы невинны они не были, могут неприятно осложниться»» [Или весенняя ..., 2011].

Таким образом, измена либо преуменьшается и представляется как нечто незначительное, быстротечное (интрижка, гульнуть, сходить налево / на сторону и др.), либо возвышается (запретная любовь, роман, любовь, связь, развлечение, приключение).

Этимология фразеологического оборота наставлять рога достаточно глубоко исследована в русской лингвистике [Михельсон, 1903; Иллюстров, 1915]. Как показано исследователями, у древних германцев был обычай, согласно которому мужья, отправляясь на войну, получали от своих жен шлемы из звериной кожи с рогами. «Надеть мужу рога» значило снарядить мужа в поход, что рассматривалось как синоним «остаться на воле» [Михельсон, 1903, с. 196]. Существует и другая гипотеза происхождения данного фразеологизма, в соответствии с которой один из византийских императоров Андроник Комнин (1113-1185 гг.) позволял как бы из милости охотиться в своем заповеднике мужьям тех жен, с которыми он входил в преступную связь. У того, кто пользовался приглашением 
императора, выставлялись на воротах дома оленьи рога: «Вероятно, в шутливом тоне речи перенесены рога от ворот ко лбу» [Иллюстров, 1915, с. 276].

Типичные для данного фразеологизма иллюстрации не свидетельствуют об эвфимизации речи. Частотны употребления выражения наставить рога в речевом акте сознательного огрубления речи, вызванного выражением негативных эмоций (досады, злости) по отношению к измене или ее агенту: «Правильно я ему рога наставила, и ещзе наставлю, нечего мне, как дуре, дома сидеть» [Каралис, 2003]; «Милая, да я ж все про тебя знаю, и про того (тоже гусь), кто тебя пристроил к Трунову, и как ты ему рога наставляла, и вообще все, так что грош цена всем этим твоим женским маневрам» [Шкловский, 2003]. Ср. с контекстами, в которых эвфемизмы действительно помогают смягчить эффект высказывания, выразить измену более деликатно: «Заводя связь на стороне, такой человек как бы подстраховывается, создавая возможность, в случае чего, сбежать и не быть одиноким» [Волков, 2019]. Природа измен: почему даже самый верный партнер может пойти на сторону,); «-Мне кажется, у него кто-то есть, - вдруг призналась Таня и опять заплакала. Ей нужно было с кем-то поговорить» [Трауб, 2012].

Производным от выражения наставить рога являются номинации объекта измены - рогатый, рогатая, рогоносеи. В лексикографических источниках получает толкование лишь лексема рогатый: «разг. такой, которому изменяет жена, обманутый женой» [Словарь русского ..., 1981, с. 722]. Однако в современной речи употребительна также лексема женского рода. Типичная сочетаемость данных лексем, а также контексты НКРЯ явно указывают на то, что единицы не выполняют функцию смягчения описываемой ситуации, a, напротив, используются с целью вызвать негативную реакцию собеседника: мужрогоносеи, мужчина-рогоносеи, рогатый муж, козел-рогоносеи; раскрывают отношение к обманутому мужу со стороны агента поступка, со стороны общества. Ср.: «На самом деле, пришли менты, скрутили молодого бедолагу рогоносца и увезли куда-то» [Грачев, 1999]; «Если она тебе изменяет, то тогда ревнивеи превращается в досадливого, глупого и мешающего козла-рогоносца, над речами и рогами которого она будет издеваться вместе с любовником» [Гиголашвили, 2007]. Мужчина как объект измены характеризуется, в основном, как глупый, наивный человек, который узнает об изменах жены последним.

Женщина как объект измены в русскоязычной картине мира вызывает жалость, представляется невинной жертвой: «Но есть такие рогатые жены, которые про свои рога знают, особенно, если рога эти уже выросли до невероятных размеров. «Глупенькая Мылка не знала, что она рогатая. Даже не догадывалась. Но есть такие рогатые женbl, которые про свои рога знают. Каково им их носить? Особенно, если рога эти уже выросли до невероятных размеров < ... Главное, чтоб деньги в дом приносил, жрать готовил, прислуживал и очень сильно любил свою единственную и неповторимую рогатенькую женушку» [Астра, 2018] - в приведенном отрывке подобное отношение выражается с помощью прилагательных глупенькая, рогатенькая - уменьшительно-ласкательный суффикс -еньк привносит в семантику исходного прилагательного особый оттенок; поступок «измена» получает выражение через существительное рога, при этом регулярность измен передается с помощью метафоры роста.

Видится, что употребление выражения наставить рога и его производных в современных контекстах указывает на то, что данные единицы находятся на этапе деэвфемизации.

Лексемы ветреница, ветреность, ветреник, ловелас, самец, дамский угодник, ходок, гулена, человек с низкой системой ценностей, полиамор, актуализирующие слот «Агент поступка, его свойства», имеют более общее значение по сравнению с прямыми номинациями изменник, изменнииа. Ср.: «Вылла по страстной любви, да, хорош был Юрий Петрович Лермонтов, ничего не скажешь, но ветреник. С крепостными девушками баловался, после наложницу завел, компаньонку жены Юльку Ивановну. Ее из тульского имения Арсеньевых прислали на исправление, она там юного моего родственника соблазнила»» [Нагибин, 1982]; «Ее муж-инженер, внешности самой заурядной, оказался 
ходоком, и у Шурки за тонкой перегородкой что ни день полыхали семейные скандалы» [Климонтович, 2002]; «Вор уверен, что все воруют, люеи - что все лгут, гулены - что все гуляют» [Синицына, 2002].

Эвфемизмы, актуализирующие оценку измены и ее агента, в большинстве своем являются номинациями свойств личности: ветреный, ветреная, непостоянный, любвеобильныцй, за исключением выражения рыльце в пушку, имеющего отношение к конкретному неблаговидному поступку или событию. Фразеологизм восходит к басне И.А. Крылова «Лисица и сурок». В контекстах НКРЯ данный фразеологизм используется с целью маскировки подлинной сущности обозначаемого: «Если бы мой муж так манифестовал, я бы подумала, что у него рыльце в пушку» [Форум Женщина..., 2004].

Прилагательные ветреный, непостоянный обозначают отрицательно оценочные качества, которые могут находить проявление в поступке «измена». Прилагательное любвеобильный является положительно оценочным и в контекстах, описывающих измену, позволяет акцентировать выгодное качество участника ситуации: «Однако когда Дарья вышла к ней (подразумевается любовница - прим. наше), подбежала и разом заревела молодая, некрасивая, вогнутолищая, как миска - просила Дарью пожалеть детей. А их у любвеобильного Коли оказалось четверо... Дарья сама отшила нениа» [Шапко, 2012]. Подобно другим положительно оценочным лексемам (любовь / роман / развлечение на стороне, приключение), прилагательное любвеобильный делает акцент на положительной стороне поступка.

Представление об измене как об отношениях вообще (романтических или дружеских) актуализируется с помощью единиц возлюбленный, возлюбленная, друг, подруга (подружка) обозначающих человека, с которым измена совершается. Данные единицы позволяют профилировать идею непредосудительности общения между людьми, связанными сильным чувством или душевной близостью: «Вышла ему навстречу и его неверная жена Клитемнестра, хотя и повелевшая устелить весь путь к изарскому двориу пурпурными тканями, но только и ждавшая момента, чтобы убить мужа и ияарствовать вместе со своим возлюбленным Эгистом...» [Архипова, 1997]; «Год назад мой муж завел себе подружку, не заморачиваясь, прямо на рабочем месте. Постепенно все узналось» [Шахунский, 2014]. Ср. также: «Пошла налево из-за спортивного интереса, да и в отместку мужу (узнала, что у него интрижка на стороне), подвернулся свободный парень на работе (с женатиком на такое не пошла бы, на женатиков у меня табу) и вот уже как седьмой год пошел как «дружим»» [Те, кто ..., 2013]. С помощью данных единиц «смягчается» порочная суть измены.

Единицы фаворит, фаворитка менее употребительны в современных контекстах, описывающих измену. В тех контекстах, в которых данные лексемы косвенно обозначают агента данного поступка, в фокус внимания выводится не сама измена, а более высокий статус агента поступка по отношению к контрагенту: «Она сейчас у шефра "Аметиста» ходит в фаворитках, спит с ним и мечтает его развести, чтобы самой за него выскочить» [Акимов, 2000].

\section{Заключение}

Таким образом, проведенное исследование показало, что эвфемизмы активно используются для репрезентации поступка «измена», что объясняется сложностью и деликатностью данной темы. Основная функция эвфемизмов со значением «измена»- смягчение и «камуфляж» поведения, которое осуждается, а его обсуждение - избегается. Эвфемизмы, актуализирующие ситуацию измены, создают неоднозначность, расплывчатость, семантическую неопределенность высказывания, описывающего измену, «вышучивают» данное явление, что позволяет избежать излишне прямолинейного, резкого, грубого описания данного феномена. Исследование также позволило выявить единицы, причисляемые к эвфемизмам (наставить рога, рогатый, рогоносеи), но в настоящее время находящиеся на этапе деэвфемизации, т.е. на стадии утраты смягчающего свойства. 


\section{Список источников}

1. Акимов П. 2000. Плата за страх. Москва, Вагриус, 368 с.

2. Архипова И. 1997. Музыка жизни. Москва, Вагриус, 82 с.

3. Астра Т. 2018. Свежо предание, а верится! Рогатая жена. 2 апр. Электронный ресурс. URL: https://subscribe.ru/archive/woman.relation.astra888/201810/08093241.html/ (дата обращения: 01.07.2020).

4. Богомолов Ю. 2001. Июльский снег. Теленеделя. Известия, 27 июля.

5. Быков В.В., Деркач О.А. 2003. Книга века. 1901-2000. Москва, Вагриус Плюс-Минус, $688 \mathrm{c}$.

6. Волков В. 2019. Природа измен: почему даже самый верный партнер может пойти на сторону. Электронный ресурс. URL: https://intrigue.dating/on-i-ona/priroda-izmen-pochemu-dajesamyy-vernyy-partner-mojet-poyti-na-storonu/ (дата обращения: 1.07.2020).

7. Гиголашвили М. 2007. Чертово колесо. Москва, Издательство АСТ, 770 с.

8. Гиголашвили М. 2009. Экобаба и дикарь. Зарубежные записки, 20: 1-61.

9. Грачев А. 1999. Ярый против видеопиратов. Москва, Вагриус, 412 с.

10. Джоваева И. 2011. Дарья Донцова: «Каждый имеет то, что он заслужил». Наша психология. Электронный ресурс. URL: https://www.psyh.ru/darya-dontsova-kazhdyj-imeet-to-chtoon-zasluzhil/ (дата обращения: 1.07.2020).

11. Домбровский Ю. 1966. Хранитель древностей. М., Советская Россия, 256 с.

12. Или весенняя то нега?.. Или то женская любовь?.. : Федор Иванович Тютчев и его последняя любовь Елена Денисьева. 2011. Наука и религия, 3: 20-23.

13. Иллюстров И.И. 1915. Жизнь русского народа в его пословицах и поговорках. М., 480 с.

14. Искандер Ф. 1989. Морской скорпион. Электронный pecypc. URL: http://www.lib.ru/FISKANDER/isk_ms.txt (дата обращения: 1.07.2020).

15. Исповедь нашей читательницы: «Неожиданно для себя я изменила мужу». 2020. Батона нет. Электронный ресурс. URL: http://batona.net/126585-ispoved-nashey-chitatelnicyneozhidanno-dlya-sebya-ya-izmenila-muzhu.html (дата обращения: 1.07.2020).

16. История измен - истории людей изменивших и тех, кому изменили. 2019-2021. Электронный ресурс. URL: https://istorii-izmen.ru (дата обращения: 1.07.2020).

17. Каралис Д. 2003. Роман с героиней. СПб., Издательство журнала Нева, 320 с.

18. Климонтович Н. 2002. Далее - везде...: Записки нестрогого юноши. М., Вагриус.

19. Михельсон М.И. 1903. Русская мысль и речь. Свое и чужое. Опыты русской фразеологии. Т. 2. Спб., Тип. Академии наук, 250 с.

20. Муж нашел любовницу и не может определиться кто ему нужен я или она!!! 2013. Woman.ru Электронный ресурc. URL: https://www.woman.ru/relations/marriage/thread/4291952/ (дата обращения: 1.07.2020).

21. Нагибин Ю. 1982. Заступница. Электронный pecypc. URL: https://libking.ru /books/poetry-/dramaturgy/521971-yuriy-nagibin-zastupnitsa.html (дата обращения: 1.07.2020).

22. НКРЯ - Национальный корпус русского языка. URL: http://ruscorpora.ru (дата обращения: 07.03.2021).

23. От порчи на мужа (если женщину бросил муж или стал похаживать «на сторону). 2019. Электронный ресурс. URL: https://magic-taro.com/threads/ot-porchi-na-muzha-esli-zhenschinubrosil-muzh-ili-stal-poxazhivat-na-storonu.11871/ (дата обращения: 1.07.2020).

24. Роман «на стороне». Как сохранить все в тайне? 2019. Белновости. Электронный pecypc. URL: https://www.belnovosti.by/lyubov-i-semya/roman-na-storone-kak-sohranit-vse-v-tayne (дата обращения: 1.07.2020).

25. Сеничкина Е.П. 2008. Словарь эвфемизмов русского языка. М., Флинта, 464 с.

26. Синицына В. 2002. Муза и генерал. Москва, Вагриус, 320 с.

27. Словарь русского языка. 1981. Под ред. А.П. Евгеньевой. Т. 1. М., Русский язык, 699 с.

28. Словарь русской ментальности. 2014. Под ред. В.В. Колесова. Т. 1. Спб., Златоуст, 592 с.

29. Сухов Е. 2007. Делу конец - сроку начало. Москва, Эксмо, 320 с.

30. Те, кто замужем и у кого есть любовник, зайдите! 2013. Woman.ru Электронный pecypc. URL: https://www.woman.ru/relations/men/thread/4352366/ (дата обращения: 1.07.2020). $1147 \mathrm{c}$.

31. Токарев С.А. 2008. Мифы народов мира. Энциклопедия. М., Советская Энциклопедия,

32. Трауб М. 2012. Замочная скважина. Москва, Эксмо, 288 с. 
33. Троицкий А. 2000. Удар из прошлого. Москва, Вагриус Плюс-Минус, 384 с.

34. Тронина Т. 2004. Русалка для интимных встреч. Москва, Эксмо, 384 с.

35. Форум Женщина + мужчина: Брак. 2004. Электронный pecypc. URL: https: //eva.ru/static/forums/46/2004_5 (дата обращения: 1.07.2020).

36. Фрумкин И. 2002. Понты дороже денег. Известия, 31 янв.

37. Шапко В. 2012. Графомания как болезнь моего серого вещества. Волга, 11.

38. Шахунский А. 2014.Твиттер. Электронный pecypc. URL: https: //twitter.com/anonimist052 (дата обращения: 1.07.2020).

39. Шеховцова Н., Рябинина О., Николаева Ю. 2001. Верных жен не бывает? Аргументы и факты, № 10.

100.

40. Шкловский Е. 2003. Сладкая парочка. Кладезь. Лазик и Паша-Король. Звезда, 9: 88-

41. Matthews P.H. 1997. Euphemism. The Concise Oxford Dictionary of Linguistics. Oxford, Oxford University Press: 119.

\section{Список литературы}

1. Апресян Ю.Д. 1995. Избранные труды. Том 1. Лексическая семантика. Синонимические средства языка. М., Школа «Языки русской культуры», Издательская фирма «Восточная литература» РАН, 472 с.

2. Афанасьев В., Гилинский Я. 1993. Социология девиантного (отклоняющегося) поведения. СПб., Питер, 167 с.

3. Байбурин А.К. 2005. Жилище в обрядах и представлениях восточных славян. 2-е изд. М., ЯСК, 224 c.

4. Балли Ш. 1961. Французская стилистика. Пер. с фр. К.А. Долинина. Под ред. Е.Г. Эткинда. М., Изд-во иностр. лит., 394 с. (Ball et Ch. 1951. Traité de stylistique française. P., Klincksieck. Vol. 1. 331 p.; Vol. 2. 264 p.)

5. Баранов А.Н. 2003. Введение в прикладную лингвистику. М., Едиториал УРСС, 360 с.

6. Видлак С. 1965. Проблема эвфемизма на фоне теории языкового поля. В кн.: Этимология. Материалы и исследования по индоевропейским и другим языкам. Под ред. Ж.Ж. Варбот, Л.А Гиндина, Г.А. Климова, В.А. Меркуловой, В.Н. Топорова, О.Н. Трубачева. М., Наука СССР: 267-285.

7. Гируцкий А.А. 2005. Табу и эвфемизмы. В кн. Введение в языкознание. Минск, ТетраСистемс: 126-129.

8. Кацев А.М. 1988. Языковое табу и эвфемия. Л., Ленингр. гос. пед. ин-т им. А.И. Герцена, 80 с.

9. Кашкин Е.В., Ляшевская О.Н. 2013. Семантические роли и сеть конструкций в системе FrameBank. В кн. Компьютерная лингвистика и интеллектуальные технологии. Сб. материалов ежегодной Международной конференции «Диалог», Бекасово, 29 мая - 2 июня 2013 г. Под ред. В.П. Селегей. В 2-х т. Т. 1: Основная программа конференции. Вып. 12(19). М., Изд-во РГГУ: 325-343.

10. Киселева И.В. 2012. Правый и левый в русской языковой картине мира. Автореферат дис. ... канд. филол. наук. М., 26 с.

11. Ковшова М.Л. 2007. Семантика и прагматика эвфемизмов. М., Гнозис, 320 с.

12. Красных В.В. 2016. Словарь и грамматика лингвокультуры; Основы психолингвокультурологии. М., Гнозис, $496 \mathrm{c.}$

13. Крысин Л.П. 2000. Эвфемизмы в современной речи. В кн. Воронцова В.Л., Гловинская М.Я., Голанова Е.И. и др. Русский язык конца ХХ столетия (1985-1995). Под ред. Е.А. Земской. М., ЯРК: 384-408.

14. Москвин В.П. 2001. Эвфемизмы: системные связи, функции и способы образования. Вопросы языкознания. 3: 58-70.

15. Торопцева Е.Н. 2003. Эвфемистические наименования в аспектах языка, истории, культуры. Дис. ... канд. филол. наук. М., 193 с.

16. Шейгал Е.И. 2000. Семиотика политического дискурса. Волгоград, Перемена, 368 с.

17. Link B., Phlean J. 2001. Conceptualizing Stigma. Annual review of sociology, 27: 363-385. DOI: https://doi.org/10.1146/annurev.soc.27.1.363

18. Neaman J.C., Silver C.G. 1995. The Wordsworth Book of Euphemisms: The Hilarious Guide to the Unmentionable. London, Cumberland House: 3-11. 


\section{References}

1. Apresyan Yu.D. 1995. Izbrannye trudy [Selected Works]. Vol. 1. Leksicheskaya semantika. Sinonimicheskie sredstva yazyka [Lexical semantics. Synonymous language means]. M., Publ. Shkola «Yazyki russkoy kul'tury», Izdatel'skaya firma «Vostochnaya literatura» RAN, 472 p.

2. Afanas'ev V., Gilinskiy Ya. 1993. Sotsiologiya deviantnogo (otklonyayushchegosya) povedeniya [Sociology of deviant (deviant) behavior]. SPb., Publ. Piter, $167 \mathrm{p}$.

3. Bayburin A.K. 2005. Zhilishche v obryadakh i predstavleniyakh vostochnykh slavyan [Dwelling in the rituals and performances of the Eastern Slavs]. M., Publ. YaSK, 224 p.

4. Balli Sh. 1961. Frantsuzskaya stilistika [French stylistics]. Per. s fr. K.A. Dolinina. Ed. E.G. Etkind. M., Publ. Izd-vo inostr. lit., 394 p. (Ball et Ch. 1951. Traité de stylistique française. P., Klincksieck. Vol. 1. 331 p.; Vol. 2. 264 p.)

5. Baranov A.N. 2003. Vvedenie v prikladnuyu lingvistiku [Introduction to Applied Linguistics]. M., Publ. Editorial URSS, 360 p.

6. Vidlak S. 1965. Problema evfemizma na fone teorii yazykovogo polya [The problem of euphemism against the background of the theory of the language field]. In: Etimologiya [Etymology]. Materialy i issledovaniya po indoevropeyskim i drugim yazykam. Eds. Zh.Zh. Varbot, L.A Gindin, G.A. Klimov, V.A. Merkulova, V.N. Toporov, O.N. Trubachev. M., Publ. Nauka SSSR: 267-285.

7. Girutskiy A.A. 2005. Tabu i evfemizmy [Taboos and euphemisms]. In: Vvedenie v yazykoznanie [Introduction to linguistics]. Minsk, Publ. TetraSistems: 126 - 129.

8. Katsev A.M. 1988. Yazykovoe tabu i evfemiya [Language taboo and euphemia]. L., Publ. Leningr. gos. ped. in-t im. A.I. Gertsena, 80 p.

9. Kashkin E.V., Lyashevskaya O.N. 2013. Semanticheskie roli i set' konstruktsiy v sisteme FrameBank [Semantic Roles and the Network of Constructions in the FrameBank System]. In: Komp'yuternaya lingvistika i intellektual'nye tekhnologii [Computational linguistics and intelligent technologies]. Cb. materialov ezhegodnoy Mezhdunarodnoy konferentsii «Dialog», Bekasovo, 29 maya 2 iyunya 2013 g. Ed.V. P. Selegey. V 2-kh vol. Vol. 1: Osnovnaya programma konferentsii [The main program of the conference]. Iss. 12 (19). M., Publ. Izd-vo RGGU: 325-343.

10. Kiseleva I.V. 2012. Pravyy i levyy v russkoy yazykovoy kartine mira [Right and Left in the Russian Language Picture of the World]. Abstract dis. ... Cand. philol. sciences. M., 26 p.

11. Kovshova M.L. 2007. Semantika i pragmatika evfemizmov [Semantics and pragmatics of euphemisms]. M., Publ. Gnozis, 320 p.

12. Krasnykh V.V. 2016. Slovar' i grammatika lingvokul'tury; Osnovy psikholingvokul'turologii [Dictionary and grammar of linguoculture; Fundamentals of psycholinguoculturology]. M., Publ. Gnozis, 496 p.

13. Krysin L.P. 2000. Evfemizmy v sovremennoy rechi [Euphemisms in modern speech]. In: Vorontsova V.L., Glovinskaya M.Ya., Golanova E.I. et al. Russkiy yazyk kontsa XX stoletiya (1985-1995) [Russian language of the late XX century (1985-1995)]. Ed. E.A. Zemskay. M., Publ. YaRK: 384-408.

14. Moskvin V.P. 2001. Evfemizmy: sistemnye svyazi, funktsii i sposoby obrazovaniya [Euphemisms: Systemic Connections, Functions and Methods of Education]. Voprosy Jazykoznanija, 3: 58-70.

15. Toroptseva E.N. 2003. Evfemisticheskie naimenovaniya $v$ aspektakh yazyka, istorii, kul'tury [Euphemistic names in the aspects of language, history, culture]. Dis. ... Cand. philol. sciences. M., 193 p.

16. Sheygal E.I. 2000. Semiotika politicheskogo diskursa [Semiotics of Political Discourse]. Volgograd, Publ. Peremena, 368 p.

17. Link B., Phlean J. 2001. Conceptualizing Stigma. Annual review of sociology, 27: 363-385. DOI: https://doi.org/10.1146/annurev.soc.27.1.363

18. Neaman J.C., Silver C.G. 1995. The Wordsworth Book of Euphemisms: The Hilarious Guide to the Unmentionable. London, Cumberland House: 3-11.

\section{ИНФОРМАЦИЯ ОБ АВТОРЕ}

Бушуева Людмила Александровна, доктор филологических наук, доцент кафедры зарубежной лингвистики ИФиЖ Национального исследовательского государственного университетв им. Н.И. Лобачевского, г. Нижний Новгород, Россия

\section{INFORMATION ABOUT THE AUTHOR}

Lyudmila A. Bushueva, Doctor of Philology, Associate Professor of the Department of Foreign Linguistics, Institute of Philosophy and Literature, National Research State University named after N.I. Lobachevsky, Nizhny Novgorod, Russia 